\title{
Non-ischemic cardiomyopathy after rituximab treatment for membranous nephropathy
}

\author{
Wisit Cheungpasitporn ${ }^{1}$, Stephen L. Kopecky ${ }^{2}$, Ulrich Specks ${ }^{3}$, Kharmen Bharucha ${ }^{1}$, Fernando C. Fervenza ${ }^{{ }^{*}}$ \\ ${ }^{1}$ Division of Nephrology and Hypertension, Department of Internal Medicine, Mayo Clinic, Rochester, MN, USA \\ ${ }^{2}$ Department of Cardiology, Mayo Clinic, Rochester, MN, USA \\ ${ }^{3}$ Division of Pulmonary and Critical Care Medicine, Department of Internal Medicine, Mayo Clinic, Rochester, MN, USA
}

\section{A R T I C L E I N F O}

Article Type:

Case Report

Article History:

Received: 8 August 2016

Accepted: 14 October 2016

Published online: 2 November 2016

Keywords:

Rituximab

Membranous nephropathy

Cardiovascular disease

Cardiomyopathy

Adverse effect

\begin{abstract}
A B S T R A C T
Rituximab is an anti-CD20 monoclonal antibody frequently used for the treatment of nonHodgkin's lymphoma, chronic lymphocytic leukemia (CLL), rheumatoid arthritis (RA), and anti-neutrophilic cytoplasmic antibody (ANCA)-associated vasculitis. In addition, rituximab has recently been increasingly used as an off-label treatment in a number of inflammatory and systemic autoimmune diseases. It is advised that rituximab infusion may cause infusion reactions and adverse cardiac effects including arrhythmia and angina, especially in patients with prior history of cardiovascular diseases. However, its detailed cardiotoxicity profile and effects on cardiac function were not well described. We report a 51-year-old man who developed non-ischemic cardiomyopathy after rituximab treatment for membranous nephropathy. The patient experienced reduced cardiac functions within 48 hours after the initial infusion, which remained markedly reduced at 9-month follow-up. As the utility of rituximab expands, physicians must be aware of this serious cardiovascular adverse effect.
\end{abstract}

Implication for health policy/practice/research/medical education:

Rituximab is currently approved by the US Food and Drug Administration (FDA) for the treatment of non-Hodgkin's lymphoma (NHL), chronic lymphocytic leukemia (CLL), rheumatoid arthritis (RA), antineutrophil cytoplasmic antibody (ANCA)associated vasculitis. In addition, rituximab has recently been used as an off-label treatment in a number of diseases. However, its detailed cardiotoxicity profile and effects on cardiac function are not clearly described in the literature. This case of non-ischemic cardiomyopathy after infusion of rituximab for membranous nephropathy highlights the growing evidence that rituximab can affect cardiac function and requires greater attention as a causative agent of cardiomyopathy.

Please cite this paper as: Cheungpasitporn W, Kopecky SL, Specks US, Bharucha K, Fervenza FC. Non-ischemic cardiomyopathy after rituximab treatment for membranous nephropathy. J Renal Inj Prev. 2017;6(1):18-25. Doi: 10.15171/jrip.2017.04

\section{Introduction}

Rituximab, a chimeric monoclonal anti-CD20 antibody, is currently approved by the US Food and Drug Administration (FDA) for the treatment of non-Hodgkin's lymphoma (NHL), chronic lymphocytic leukemia (CLL), rheumatoid arthritis (RA), antineutrophil cytoplasmic antibody (ANCA)-associated vasculitis including granulomatosis with polyangiitis (GPA) and microscopic polyangiitis (MPA) (1-5). In addition to these indications, the use of rituximab has been expanded as an off-label treatment for many diseases including systemic lupus erythematosus, Sjögren's syndrome, idiopathic thrombocytopenic purpura, bullous dermatologic diseases, membranous nephrop- athy, steroid-dependent or frequently relapsing idiopathic nephrotic syndrome, treatment in recurrent and de novo glomerular disease after renal transplantation, and others (6-9).

Despite its relative safety profile, infusion-related side effects of rituximab, such as fevers, chills and rigors are common, reported to be as high as $87 \%(2-5,10,11)$. Due to reported cases of angina, acute coronary syndrome (ACS), and arrhythmias related to rituximab infusion, caution for its use is advised by FDA in patients with a history of cardiovascular disease (12). However, its detailed cardiotoxicity profile and effects on cardiac function are not clearly described in the medical literature. We report 
a case of a 51-year-old man who developed non-ischemic cardiomyopathy after receiving his first infusion of rituximab for membranous nephropathy. This case highlights the growing evidence that rituximab can affect cardiac function and requires greater attention as a potential causative agent of cardiomyopathy.

\section{Case Presentation}

A 51-year-old man was diagnosed with phospholipase A2 receptor (PLA2R) positive, primary membranous nephropathy. He was initially treated with prednisone and cyclophosphamide without significant improvement. The patient was subsequently started on tacrolimus and became calcineurin inhibitor-dependent. Due to a relapse despite being on tacrolimus, rituximab treatment was recommended. His past medical history was remarkable for multiple episodes of deep venous thrombosis on chronic anticoagulation, hypertension, and dyslipidemia. He did not have any previous cardiac history and denied any concerning preceding cardiac symptoms of chest pain, dyspnea, syncope, orthopnea, or paroxysmal nocturnal dyspnea. The patient had a 33-pack-year history of smoking but quit two years previously. His 12-lead electrocardiogram (ECG) prior to rituximab treatment showed normal sinus rhythm. He worked as a carpenter and had been carrying heavy equipment at work without significant physical limitation. His family history is significant for coronary artery disease in his father at 50 years of age and dilated cardiomyopathy (DCM) in his brother. Due to significant cardiovascular diseases in his family members the patient underwent a cardiolite treadmill stress test which showed normal exercise tolerance and functional class I on Bruce protocol for 15 minutes. There was no evidence of fixed or reversible defect.

The patient was $179 \mathrm{~cm}$ tall with a body weight of $88 \mathrm{~kg}$ and body surface area (BSA) of $2.1 \mathrm{~m}^{2}$. Rituximab was administered at a dosage of $1000 \mathrm{mg}$ intravenous (IV) at a starting infusion rate of $50 \mathrm{~mL} / \mathrm{h}$. Oral acetaminophen (1000 mg), oral diphenhydramine (50 mg), and IV methylprednisolone $(100 \mathrm{mg}$ ) were also given as premedication. He underwent his first rituximab infusion without any immediate side effects. Forty-eight hours after the infusion, the patient presented to the hospital and reported having woken up from sleep with chest tightness and shortness of breath. He also had nausea and emesis. His physical examination was unremarkable with no evidence of heart failure.

A 12-lead ECG showed a new left bundle branch block (LBBB) as shown in Figure 1. Troponin I level was 0.08 $\mathrm{ng} / \mathrm{mL}$ (normal $<0.03 \mathrm{ng} / \mathrm{mL}$ ). Otherwise, Laboratory testing revealed the following values: hemoglobin 11.2 $\mathrm{g} / \mathrm{dL}$ (reference range 13.5-17.5 g/dL), white blood cell count $9.6 \times 10^{9} / \mathrm{L}$ (reference range 3.5-10.5 $\times 10^{9} / \mathrm{L}$ ), platelet $157 \times 10^{9} / \mathrm{L}$ (reference range $150-450 \times 10^{9} / \mathrm{L}$ ), serum creatinine $1.5 \mathrm{mg} / \mathrm{dL}$ (reference range $0.8-1.3 \mathrm{mg} / \mathrm{dL}$ ), BUN $41 \mathrm{mg} / \mathrm{dL}$ (reference range $8-24 \mathrm{mg} / \mathrm{dL}$ ), sodium 141 $\mathrm{mmol} / \mathrm{L}$ (reference range $135-145 \mathrm{mmol} / \mathrm{L}$ ), potassium 5.0 $\mathrm{mmol} / \mathrm{L}$ (reference range 3.6-5.2 $\mathrm{mmol} / \mathrm{L}$ ), chloride 111 $\mathrm{mmol} / \mathrm{L}$ (reference range 100-108 $\mathrm{mmol} / \mathrm{L}$ ), bicarbonate $22 \mathrm{mmol} / \mathrm{L}$ (reference range $22-29 \mathrm{mmol} / \mathrm{L}$ ). Computed tomography angiogram of the chest was negative for pulmonary embolism without evidence of significant coronary calcification. An urgent transthoracic echocardiogram demonstrated moderately reduced left ventricular (LV) systolic function with an ejection fraction (EF) of $30 \%$ with moderate hypokinesis of the anteroseptal myocardium. There was no significant valvular disease. The patient subsequently underwent left and right heart catheterization with coronary angiography which revealed a cardiac output of $5.9 \mathrm{~L} / \mathrm{min}$ (normal range: $4-8 \mathrm{~L} / \mathrm{min}$ ) and a cardiac index of $2.88 \mathrm{~L} / \mathrm{min} / \mathrm{m}^{2}$ (normal range: $2.6-4.2 \mathrm{~L}$ / $\mathrm{min} / \mathrm{m}^{2}$ ). There was no significant atherosclerotic disease noted in the coronary vessels. However, there was moderate diffuse hypokinesis of the LV on ventriculogram. Right heart catheterization demonstrated mildly elevated right and left-sided filling pressures. Thus, the diagnosis of non-ischemic cardiomyopathy was made, and the underlying etiology of his non-ischemic cardiomyopathy was postulated to be due to rituximab treatment.

The patient received medical treatment for the cardiomyopathy with carvedilol $3.125 \mathrm{mg}$ orally twice a day as well as lisinopril $10 \mathrm{mg}$ and rosuvastatin $10 \mathrm{mg}$ orally once a day. The patient was also subsequently placed on a life vest due to prevent sudden cardiac death. The patient was restarted on tacrolimus for his treatment of membranous nephropathy. He did not receive any further treatment with rituximab. A repeat echocardiogram one month later still demonstrated severe LV enlargement with a calculated EF of 26\%. There was persistent generalized LV hypokinesis with abnormal ventricular septal wall motion due to LBBB. Otherwise, there was a mild valvular heart disease. His follow-up ECG showed normal sinus rhythm with LBBB. Carvedilol was increased to $6.25 \mathrm{mg}$ twice a day and slowly titrated up to $25 \mathrm{mg}$ twice a day. At 9-month follow-up, despite that he had better optimization of his medical therapy, his transthoracic echocardiogram still showed reduced LVEF of $31 \%$ with moderate-severe LV enlargement. Thus, the patient was evaluated and underwent cardiac resynchronization therapy with implantable cardioverter defibrillators (CRT-D) implantation. At 3

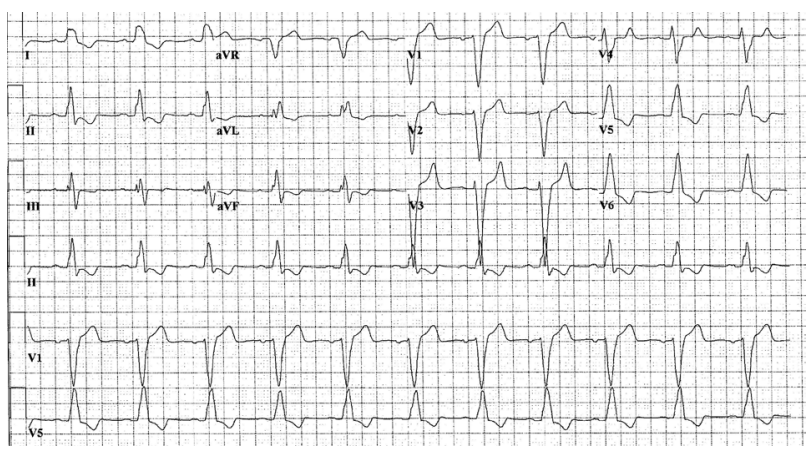

Figure 1. A 12-lead electrocardiogram showed ventricular rate of 68 beats/min, normal sinus rhythm, and left bundle branch block. 
month after initiation of CRT therapy, the patient had significant improvement in his functional status with LVEF of $52 \%$. Although the patient still had proteinuria at 607 $\mathrm{mg} / \mathrm{dL} / 24$ hours, his kidney function remained stable with creatinine of $1.6 \mathrm{mg} / \mathrm{dL}$ and creatinine clearance of $69 \mathrm{~mL} /$ $\mathrm{min} / \mathrm{BSA}$.

\section{Discussion}

Rituximab, B-cell-depleting agent targeting CD20 antigen, is being increasingly and effectively used "off label" for various conditions including glomerular diseases such as lupus nephritis, membranous nephropathy, focal segmental glomerulosclerosis, cryoglobulinemic glomerulonephritis, antibody-mediated renal allograft rejection and recurrent glomerulonephritis in renal allograft $(6-9,13)$. However, the data regarding its cardiac side effect profile are not well recognized. We report a rare, but serious cardiac adverse effect of irreversible/partial reversible nonischemic cardiomyopathy following rituximab treatment in a patient with membranous nephropathy.

To identify potential previously reported cases of potential cardiovascular adverse effects related to rituximab treatment, the literature searches of Embase, Medline and Cochrane through July 2016 was performed using the terms "rituximab" and "rituxan" combined with the terms "cardiac", "cardiovascular", "cardiomyopathy", "coronary" and "heart". Not surprisingly, some reports have stated that rituximab is safe for the heart (2-5). This finding is also consistent with the data from our recent published data from a multicenter, randomized, double-blind controlled trial comparing the efficacy of rituximab with conventional immunosuppression with cyclophosphamide for the treatment of severe ANCA-associated vasculitis in 197 patients (1). There was no significant difference in serious or non-disease-related adverse event between two groups. Also, significant or serious cardiovascular adverse effects were not noted.

Rituximab is well known to cause infusion-related side effects from cytokine release, such as fevers and rigors within the first few hours, especially during the first infusion. These symptoms are associated with cytokine release, particularly interleukin 6 (IL-6). Most of these cases resolve promptly with supportive management. Hypotension, angioedema, hypoxia, and bronchospasm can also be seen in up to $10 \%$ of cases $(10,11)$. With previously reported cases of angina, ACS, and arrhythmias with rituximab infusion (14-25), FDA has cautiously provided recommendations to discontinue infusions for serious or life-threatening cardiac arrhythmias and perform cardiac monitoring during and after all infusions of rituximab for patients who develop clinically significant arrhythmias, or who have a history of arrhythmia or angina (12). However, these current recommendations do not sufficiently address the cardiovascular concerns related to rituximab treatment, since cases with adverse cardiovascular effects following rituximab infusion have been additionally reported as shown in Table 1. In addition to ACS and arrhythmia, rituximab-induced cardiogenic shock, delayed reduction in LVEF, Takotsubo's and non-ischemic cardiomyopathies have also been described $(14-23,25,26)$ as summarized in Table 2 .

Interestingly, in a randomized controlled trial of singledose rituximab as induction in renal transplantation, Tydén et al (27) reported a statistically significant increase in mortality in the rituximab group at 3-year follow-up and $75 \%$ of deaths in rituximab-treated recipients were from cardiovascular causes. In a report of 120 patients with follicular and mantle-cell lymphoma treated with rituximab (28), cardiovascular death was reported in 3 of 4 deaths within 12 months. According to the analysis of mortality associated with rituximab use in autoimmune diseases between 2000 and 2013, fatal outcomes were found in 14 patients out of 134 patients (10.4\%). While the majority of patients died from infections, $8 \%$ died after cardiac events (29). These findings in addition to reported cases of ACS/myocardial infarction associated with the infusion of rituximab (Table 1) raise the concern of its cardiac side effect profile from rituximab since Blymphocytes, particularly B1a-lymphocytes, were recently found to provide an atheroprotective effect (30). Besides, ACS due to coronary vasospasm following rituximab infusion was also reported (19).

Cardiovascular toxicity in the form of cardiac arrhythmias has been reported in $8 \%$ of patients treated with rituximab (2). These include monomorphic ventricular tachycardia, polymorphic ventricular tachycardia, supraventricular tachycardia, trigeminy, bradycardia, atrial fibrillation and nonspecific dysrhythmias or tachycardia $(2,18,31-35)$. It is postulated that the CD 20 antigen also may affect the calcium ion channel (18). The therapeutic action of rituximab may act by cell lysis via complement-dependent cytotoxicity, antibody-dependent cellular cytotoxicity, and apoptosis. The CD20 antigen is present on immuneeffector cells and, after cytotoxic-mediated lysis; it could sequester itself in normal tissues of the body, including cardiac myocytes. It is possible that rituximab affects conduction by inhibiting the calcium-ion-channel properties of the CD20 antigen. Inhibition of calcium-ion channels in cardiac myocytes could lead to the formation of early after-depolarization (18).

Kanamori et al (16) reported delayed effect ( $>2$ weeks following rituximab infusion) of reduced LVEF in 3 cases with NHL (Table 1). The prognosis was different in each reported case. Of 3 patients, one had irreversible cardiomyopathy and died with severe heart failure. Partially reversible cardiomyopathy was also recently observed in a case of CLL with cardiomyopathy during treatment with rituximab (24). In contrast to these reported cases, our case presentation provided very important evidence that rituximab can affect cardiac function. Firstly, in previously reported cases of rituximab induced non-ischemic cardiomyopathy; other concurrent chemotherapeutic agents in addition to rituximab were also given. Thus, it was not conclusive that rituximab was the causative agent. In our case presentation, the patient received only rituximab as a single agent for treatment. Secondly, our case 
Table 1. Reported cases with cardiovascular adverse effect following rituximab infusion

\begin{tabular}{|c|c|c|c|c|c|c|c|c|c|c|c|}
\hline & Year & $\begin{array}{l}\text { No. of } \\
\text { cases }\end{array}$ & Demographics & $\begin{array}{l}\text { Indication for } \\
\text { Rituximab } \\
\text { treatment }\end{array}$ & $\begin{array}{l}\text { Cardiovascular } \\
\text { toxicities }\end{array}$ & Onset & Prior cardiac history & $\begin{array}{l}\text { Electrocardiogram (Post } \\
\text { infusion) }\end{array}$ & Echocardiogram & Coronary angiography & Outcomes \\
\hline $\begin{array}{l}\text { Garypidou } \\
\text { et al (14) }\end{array}$ & 2004 & 1 & $\begin{array}{l}\text { A 71-year-old } \\
\text { male }\end{array}$ & $\begin{array}{l}\text { Non-Hodgkin } \\
\text { lymphomas and } \\
\text { B-cell chronic } \\
\text { lymphocytic } \\
\text { leukemia }\end{array}$ & $\begin{array}{l}\text { Unstable angina/ } \\
\text { acute coro-nary } \\
\text { syndrome }\end{array}$ & $\begin{array}{l}\text { Four hours after the } \\
\text { initiation of the first } \\
\text { infusion }\end{array}$ & $\begin{array}{l}\text { Myocardial infarction } 12 \text { years } \\
\text { previously }\end{array}$ & $\begin{array}{l}\text { Sinus tachycardia with } \\
\text { no ST-segment or T-wave } \\
\text { changes }\end{array}$ & NR & NR & $\begin{array}{l}\text { The pain resolved with } \\
\text { the administration of } \\
\text { nitroglycerin sublingually } \\
\text { and the infusion was } \\
\text { interrupted. During the } \\
\text { next few days, there } \\
\text { was no elevation of the } \\
\text { biochemical cardiac } \\
\text { markers or ECG changes. }\end{array}$ \\
\hline $\begin{array}{l}\text { Millward } \\
\text { et al (15) }\end{array}$ & 2005 & 1 & $\begin{array}{l}\text { A 20-year-old } \\
\text { female }\end{array}$ & $\begin{array}{l}\text { Refractory } \\
\text { thrombotic } \\
\text { thrombocytopenia } \\
\text { purpura }\end{array}$ & Cardiogenic shock & $\begin{array}{l}\text { Six hours after the } \\
\text { rituximab infusion }\end{array}$ & None & NR & $\begin{array}{l}\text { Acute biventricular } \\
\text { cardiogenic shock } \\
\text { with EF of 5\%-10\% }\end{array}$ & NR & $\begin{array}{l}1 \text { week after cardiogenic } \\
\text { shock, biventricular } \\
\text { systolic and diastolic } \\
\text { functions were } \\
\text { normalized. }\end{array}$ \\
\hline $\begin{array}{l}\text { Kanamori } \\
\text { et al (16) }\end{array}$ & 2006 & 3 & $\begin{array}{l}\text { A } 80 \text {-year-old } \\
\text { man, } 65 \text {-year- } \\
\text { old man, and } 55 \\
\text { year-old man }\end{array}$ & $\begin{array}{l}\text { Non-Hodgkin's } \\
\text { lymphoma }\end{array}$ & $\begin{array}{l}\text { Delayed reduction } \\
\text { in LV function }\end{array}$ & $\begin{array}{l}\text {-Case 1: } 2 \text { weeks } \\
\text { after rituxi-mab } \\
\text {-Case 2: after the } \\
\text { sixth course } \\
\text {-Case 3: after the } \\
\text { fourth course }\end{array}$ & $\begin{array}{l}\text {-Case 1: no risk factor for cor- } \\
\text { onary artery disease } \\
\text {-Case 2: smoking } \\
\text {-Case 3: smoking }\end{array}$ & NR & $\begin{array}{l}\text {-Case 1: EF } 35 \% 2 \\
\text { weeks after rituximab } \\
\text {-Case 2: EF decreased } \\
\text { to } 50 \% \text { after the sixth } \\
\text { course from } 65 \% \\
\text { before treatment } \\
\text {-Case 3: EF decreased } \\
\text { to } 55 \% \text { after the } \\
\text { fourth course } \\
\text { from } 73 \% \text { before } \\
\text { treatment }\end{array}$ & NR & $\begin{array}{l}\text {-Case 1: died } \\
\text {-Case 2: asymptomatic } \\
\text {-Case 3: recovered one } \\
\text { month after treatment }\end{array}$ \\
\hline $\begin{array}{l}\text { Armitage } \\
\text { et al (17) }\end{array}$ & 2008 & 3 & $\begin{array}{l}\text { The median age } \\
\text { of } 61 \text { years }\end{array}$ & $\begin{array}{l}\text { Lymphoproliferative } \\
\text { disorders }\end{array}$ & $\begin{array}{l}\text { Acute coronary } \\
\text { syndromes }\end{array}$ & $\begin{array}{l}\text { Initial infusion of } \\
\text { rituximab }\end{array}$ & $\begin{array}{l}\text { One patient had known } \\
\text { athero-sclerotic heart disease, } \\
\text { and } 2 \text { patients had risk factors } \\
\text { for coronary artery disease }\end{array}$ & NR & NR & NR & $\begin{array}{l}\text { One patient died of } \\
\text { an ar-rhythmia that } \\
\text { deteriorated into asystole, } \\
\text { and } 2 \text { patients recov-ered } \\
\text { and underwent coronary } \\
\text { angiography }\end{array}$ \\
\hline
\end{tabular}


Table 1. Reported cases with cardiovascular adverse effect following rituximab infusion (Cont.)

\begin{tabular}{|c|c|c|c|c|c|c|c|c|c|c|c|}
\hline & Year & $\begin{array}{l}\text { No. of } \\
\text { cases }\end{array}$ & Demographics & $\begin{array}{l}\text { Indication for } \\
\text { Rituximab } \\
\text { treatment }\end{array}$ & $\begin{array}{l}\text { Cardiovascular } \\
\text { toxicities }\end{array}$ & Onset & Prior cardiac history & $\begin{array}{l}\text { Electrocardiogram (Post } \\
\text { infusion) }\end{array}$ & Echocardiogram & Coronary angiography & Outcomes \\
\hline $\begin{array}{l}\text { Poterucha } \\
\text { et al (18) }\end{array}$ & 2010 & 1 & $\begin{array}{l}\text { A 79-year-old } \\
\text { woman }\end{array}$ & $\begin{array}{l}\text { Malignant } \\
\text { lymphoma }\end{array}$ & $\begin{array}{l}\text { Polymorphic } \\
\text { ventricular } \\
\text { tachycardia. }\end{array}$ & $\begin{array}{l}\text { Thirty minutes into } \\
\text { the initial infusion of } \\
\text { rituximab }\end{array}$ & $\begin{array}{l}\text { A history of atrial flutter post } \\
\text { atrioventricular nodal ablation } \\
1 \text { year before, followed by } \\
\text { placement of a pacemaker } \\
\text { with } 100 \% \text { ventricular-paced }\end{array}$ & $\begin{array}{l}\text { No ischemic changes, } \\
\text { atrial fibrillation with VVIR } \\
\text { pacing. The QT interval was } \\
\text { technically prolonged. } \\
\text { Interrogation of } \\
\text { pacemaker's intracardiac } \\
\text { electrogram revealed } \\
\text { a 12-second run of } \\
\text { polymorphic VT }\end{array}$ & NR & NR & $\begin{array}{l}\text { Discharged from the } \\
\text { hospital a day later } \\
\text { No recurrence of } \\
\text { arrhythmia at 3-year } \\
\text { follow-up }\end{array}$ \\
\hline $\begin{array}{l}\text { Lee et al } \\
\text { (19) }\end{array}$ & 2012 & 1 & $\begin{array}{l}\text { A 52-year-old } \\
\text { woman }\end{array}$ & $\begin{array}{l}\text { Follicular } \\
\text { lymphoma }\end{array}$ & $\begin{array}{l}\text { Coronary } \\
\text { vasospasm }\end{array}$ & $\begin{array}{l}\text { Within } 10 \text { minutes of } \\
\text { first treatment }\end{array}$ & $\begin{array}{l}\text { No cardiac risk factors other } \\
\text { than a seven pack-year } \\
\text { smoking history }\end{array}$ & $\begin{array}{l}\text { New onset T-wave inversion } \\
\text { in the anterior precordial } \\
\text { leads }\end{array}$ & NR & $\begin{array}{l}\text { Normal cardiac } \\
\text { function with no } \\
\text { evidence of occlusive } \\
\text { disease in the coronary } \\
\text { arteries }\end{array}$ & $\begin{array}{l}\text { Rechallenged with } \\
\text { rituximab with continuous } \\
\text { cardiac monitoring. } \\
\text { No recurrent chest pain or } \\
\text { ECG changes }\end{array}$ \\
\hline $\begin{array}{l}\text { Passalia et } \\
\text { al (20) }\end{array}$ & 2013 & 2 & $\begin{array}{l}\text { A } 75 \text { - year-old } \\
\text { Caucasian man } \\
\text { (case 1) and a 57- } \\
\text { year-old Caucasian } \\
\text { woman (case 2) }\end{array}$ & $\begin{array}{l}\text { Stage IV } \\
\text { non-Hodgkin } \\
\text { lymphoma }\end{array}$ & $\begin{array}{l}\text {-Case 1: New onset } \\
\text { atrial fibrillation } \\
\text {-Case 2: chest pain }\end{array}$ & $\begin{array}{l}\text {-Case 1: Immediately } \\
\text { after the end of the } \\
\text { first infusion } \\
\text {-Case 2: after the } \\
\text { first } 90 \text { minutes of } \\
\text { infusion }\end{array}$ & $\begin{array}{l}\text {-Case } 1 \text { had a right } \\
\text { bundle branch block and } \\
\text { several cardiovascular risk } \\
\text { factors: cigarette smoking, } \\
\text { dyslipidemia, hypertension } \\
\text {-Case } 2 \text { the patient was a } \\
\text { smoker and had previous } \\
\text { chemotherapy including high } \\
\text { doses of anthracyclines ( } 340 \\
\text { mg cumulative dose). }\end{array}$ & $\begin{array}{l}\text {-Case 1: atrial fibrillation } \\
\text { and confirmed RBBB. } \\
\text {-Case } 2 \text { : sinus tachycardia at } \\
\text { a rate of } 118 \mathrm{bpm} \text {. }\end{array}$ & $\begin{array}{l}\text {-Case 1: normal LV } \\
\text { function with an } \\
\text { estimated EF of 50- } \\
55 \% \text {, hypertrophy of } \\
\text { the interventricular } \\
\text { septum, and mod - } \\
\text { erate tricuspid and } \\
\text { mitral regurgitation. } \\
\text {-Case 2: did } \\
\text { not reveal any } \\
\text { pathological } \\
\text { alteration }\end{array}$ & $\begin{array}{l}\text {-Case 1: Subsequent } \\
\text { coronary arteriography } \\
\text { showed multivessel } \\
\text { coronary artery } \\
\text { disease, for which the } \\
\text { patient underwent a } \\
\text { stent implantation. } \\
\text {-Case 2: the patient } \\
\text { refused to have further } \\
\text { tests }\end{array}$ & $\begin{array}{l}\text {-Case 1: survived } \\
\text {-Case 2: recurrence of } \\
\text { chest pain occurred } \\
\text { when the infusion speed } \\
\text { exceeded } 50 \mathrm{~mL} / \mathrm{h} \text { with } \\
\text { additional cycles. }\end{array}$ \\
\hline $\begin{array}{l}\text { Sellier- } \\
\text { Leclerc et } \\
\text { al (21) }\end{array}$ & 2013 & 1 & A 7-year-old boy & $\begin{array}{l}\text { Steroid- } \\
\text { dependent } \\
\text { idiopathic } \\
\text { nephrotic } \\
\text { syndrome }\end{array}$ & $\begin{array}{l}\text { Fulminant viral } \\
\text { myocarditis }\end{array}$ & $\begin{array}{l}13 \text { months after the } \\
\text { first RTX infusion }\end{array}$ & None & $\begin{array}{l}\text { Non- sustained ventricular } \\
\text { tachycardia }\end{array}$ & Cardiac dysfunction & NR & $\begin{array}{l}\text { An endomyocardial biopsy } \\
\text { was performed which } \\
\text { showed an inflammatory } \\
\text { infiltrate, vasculitis and } \\
\text { myocardial necrosis; } \mathrm{PCR} \\
\text { assay of the sample was } \\
\text { positive for enterovirus; } 2 \\
\text { months later the patient } \\
\text { successfully underwent } \\
\text { heart transplant surgery. }\end{array}$ \\
\hline
\end{tabular}


Table 1. Reported cases with cardiovascular adverse effect following rituximab infusion (Cont.)

\begin{tabular}{|c|c|c|c|c|c|c|c|c|c|c|c|}
\hline & Year & $\begin{array}{l}\text { No. of } \\
\text { cases }\end{array}$ & Demographics & $\begin{array}{l}\text { Indication for } \\
\text { Rituximab } \\
\text { treatment }\end{array}$ & $\begin{array}{l}\text { Cardiovascular } \\
\text { toxicities }\end{array}$ & Onset & Prior cardiac history & $\begin{array}{l}\text { Electrocardiogram (Post } \\
\text { infusion) }\end{array}$ & Echocardiogram & Coronary angiography & Outcomes \\
\hline Smith et al (22) & 2013 & 1 & $\begin{array}{l}\text { A } 60 \text {-year old } \\
\text { woman }\end{array}$ & Lymphoma & $\begin{array}{l}\text { Takotsubo } \\
\text { cardiomyopa-thy }\end{array}$ & $\begin{array}{l}\text { During infusion of } \\
\text { ritux-imab }\end{array}$ & $\begin{array}{l}\text { NR; an echocardiogram } 3 \text { days } \\
\text { before chemo-therapy was } \\
\text { normal }\end{array}$ & $\begin{array}{l}\text { ST-segment elevation in } \\
\text { leads V1 to V6 }\end{array}$ & $\begin{array}{l}\text { Apical ballooning } \\
\text { with hyperdynamic } \\
\text { basal segments with } \\
\text { an EF of } 20-25 \%\end{array}$ & NR & $\begin{array}{l}\text { Rituximab was discon- } \\
\text { tinued. Discharged } \\
\text { home with an angioten- } \\
\text { sin-converting enzyme } \\
\text { inhibitor and beta-blocker. } \\
\text { LVEF was im-proved to } 42 \% \\
\text { at } 1 \text { month. }\end{array}$ \\
\hline Ng et al (24) & 2015 & 1 & $\begin{array}{l}\text { A 66-year-old } \\
\text { man }\end{array}$ & $\begin{array}{l}\text { Chronic } \\
\text { lymphocytic } \\
\text { leukaemia }\end{array}$ & $\begin{array}{l}\text { Takotsubo } \\
\text { cardiomyopa-thy }\end{array}$ & $\begin{array}{l}\text { Within } 40 \text { min of the } \\
\text { in-fusion }\end{array}$ & No previous cardiac his-tory. & $\begin{array}{l}\text { Sinus tachycardia; ST } \\
\text { segment elevation in } \\
\text { leads I, II and V4-V6 }\end{array}$ & $\begin{array}{l}\text { Normal LV size with } \\
\text { hypokinesis of the } \\
\text { ante-rior wall, mild } \\
\text { mitral re-gurgitation, } \\
\text { aortic regur-gitation } \\
\text { and pericardial } \\
\text { effusion, but no signs } \\
\text { of tamponade. }\end{array}$ & $\begin{array}{l}\text { Non-obstructive } \\
\text { distal atheroma } \\
\text { with no indica-tion } \\
\text { for percutaneous } \\
\text { intervention. }\end{array}$ & $\begin{array}{l}\text { Reported no recurrence } \\
\text { of his symptoms at fol- } \\
\text { low-up. }\end{array}$ \\
\hline $\begin{array}{l}\text { Cheungpasitporn } \\
\text { et al } \\
\text { (Our case } \\
\text { presentation) }\end{array}$ & 2016 & 1 & $\begin{array}{l}\text { A 51-year-old } \\
\text { man }\end{array}$ & $\begin{array}{l}\text { Membranous } \\
\text { nephropathy }\end{array}$ & $\begin{array}{l}\text { Non-ischemic } \\
\text { cardiomyopathy }\end{array}$ & $\begin{array}{l}\text { Forty-eight hours } \\
\text { after the infusion }\end{array}$ & No previous cardiac history & New LBBB & $\begin{array}{l}\text { Moderately reduced } \\
\text { LV systolic function } \\
\text { with an EF of } 30 \% \\
\text { with moderate } \\
\text { hypokinesis of } \\
\text { anteroseptal } \\
\text { myocardium. }\end{array}$ & $\begin{array}{l}\text { No significant athero- } \\
\text { sclerotic disease } \\
\text { noted in the coronary } \\
\text { vessels. There was } \\
\text { moderate diffuse } \\
\text { hypokinesis of LV on } \\
\text { ventriculogram. }\end{array}$ & $\begin{array}{l}\text { At } 9 \text { month follow-up, } \\
\text { despite that he had bet-ter } \\
\text { optimization of his medical } \\
\text { therapy, his transthoracic } \\
\text { echocardi-ogram still } \\
\text { showed re-duced LV EF } \\
\text { of } 31 \% \text {. }\end{array}$ \\
\hline
\end{tabular}


Table 2. Summary of cardiovascular adverse effects related to rituximab treatment

\begin{tabular}{l}
\hline Cardiovascular adverse effects related to rituximab treatment \\
\hline Hypotension \\
Cardiogenic shock \\
ACS (angina, unstable angina and myocardial infarction) \\
Arrhythmia (monomorphic ventricular tachycardia, polymorphic ventricular tachycardia, supraventricular tachycardia, trigeminy, bradycardia, \\
atrial fibrillation and nonspecific dysrhythmias or tachycardia) \\
Reduction in LVEF (may occur within the first few hours after the initial infusion dose or after subsequent doses) \\
Non-ischemic Cardiomyopathy \\
Takotsubo's cardiomyopathy
\end{tabular}

had a coronary angiogram which demonstrated clean coronary artery. Thus, we could confirm the diagnosis of non-ischemic cardiomyopathy, unlike previously reported cases (16). Thirdly, our case study showed the new finding that a reduction in cardiac function can occur early within 48 hours. Lastly, this case presentation highlights an importance for obtaining family history prior to rituximab treatment. Our patient's family history is remarkable for DCM in his brother. Since familial DCM may occur in $20 \%$ to $50 \%$ of idiopathic DCM cases (36), the patient may have had an occult cardiomyopathy that was symptomatically induced by rituximab infusion.

Although the pathophysiology of rituximab induced nonischemic cardiomyopathy remains unclear, the finding from Kanamori et al (16) raised an important observation. After rituximab infusion, patients' cardiac myocytes were noted to have diffuse amounts of reticulin fiber along with increased serum transforming growth factor- $\beta$ levels. The investigators suggested that the transforming growth factor- $\beta$ levels could have led to increased reticulin fiber formation causing a decrease in myocardial contractility leading to non-ischemic cardiomyopathy (16). Also, Takotsubo cardiomyopathy (stress cardiomyopathy), an important type of non-ischemic cardiomyopathy has recently been reported after rituximab infusion (Table 1). In our case presentation, the patient had diffuse hypokinesis which was not a typical finding in Takotsubo cardiomyopathy (37). In addition, most patients with Takotsubo cardiomyopathy recover, unlike our case presentation; LVEF was still significantly reduced at 9-month follow-up.

\section{Conclusion}

In summary, awareness of cardiotoxicity profile of rituximab is important to minimize the risk of treatment-related morbidity/mortality. In addition to ACS and cardiac arrhythmia, non-ischemic cardiomyopathy can be associated with the infusion of rituximab. This condition may occur early within 48 hours. The occurrence of symptoms that could be ascribed to an ACS or heart failure with reduced ejection fraction (HFrEF) should always be taken seriously during the rituximab infusion and carefully investigated. Patients should be aware that this is a rare, albeit serious, complication of treatment with rituximab. Pretreatment echocardiogram may be helpful when considering rituximab treatment in patients who have a family history of cardiomyopathy.
Authors' contribution

All authors had access to the data and a role in writing the manuscript.

\section{Conflicts of interest}

Authors declare no conflict of interests.

\section{Ethical considerations}

Ethical issues (including plagiarism, data fabrication, double publication) have been completely observed by authors.

\section{Funding/Support}

None.

\section{References}

1. Specks U, Merkel PA, Seo P, Spiera R, Langford CA, Hoffman GS, et al. Efficacy of remission-induction regimens for ANCA-associated vasculitis. N Engl J Med. 2013;369:41727. doi: 10.1056/NEJMoa1213277.

2. Foran JM, Rohatiner AZ, Cunningham D, Popescu RA, Solal-Celigny P, Ghielmini M, et al. European phase II study of rituximab (chimeric anti-CD20 monoclonal antibody) for patients with newly diagnosed mantle-cell lymphoma and previously treated mantle-cell lymphoma, immunocytoma, and small B-cell lymphocytic lymphoma. J Clin Oncol. 2000;18:317-24.

3. Kilickap S, Yavuz B, Aksoy S, Sahiner L, Dincer M, Harputluoglu H, et al. Addition of rituximab to chop does not increase the risk of cardiotoxicity in patients with nonHodgkin's lymphoma. Med Oncol. 2008;25:437-42. doi: 10.1007/s12032-008-9062-2.

4. Ganjoo KN, An CS, Robertson MJ, Gordon LI, Sen JA, Weisenbach J, etal. Rituximab, bevacizumab and CHOP (RACHOP) in untreated diffuse large B-cell lymphoma: safety, biomarker and pharmacokinetic analysis. Leuk Lymphoma. 2006;47:998-1005. doi: 10.1080/10428190600563821.

5. Drapkin R, Di Bella NJ, Faragher DC, Harden E, Matei C, Hyman W, et al. Results of a phase II multicenter trial of pentostatin and rituximab in patients with low grade B-cell non-Hodgkin's lymphoma: an effective and minimally toxic regimen. Clin Lymphoma. 2003;4:169-75. doi: 10.3816/ CLM.2003.n.026.

6. Ruggenenti P, Ruggiero B, Cravedi P, Vivarelli M, Massella L, Marasa M, et al. Rituximab in steroid-dependent or frequently relapsing idiopathic nephrotic syndrome. J Am Soc Nephrol. 2014;25:850-63. doi: 10.1681/asn.2013030251.

7. Ponticelli C, Glassock RJ. Posttransplant recurrence of primary glomerulonephritis. Clin J Am Soc Nephrol. 
2010;5:2363-72. doi: 10.2215/cjn.06720810

8. Kattah AG, Fervenza FC, Roccatello D. Rituximab-based novel strategies for the treatment of immune-mediated glomerular diseases. Autoimmun Rev. 2013;12:854-9. doi: 10.1016/j.autrev.2012.09.002.

9. Rigal D, Meyer F. [Autoimmune haemolytic anemia: diagnosis strategy and new treatments]. Transfus Clin Biol. 2011;18:277-85. doi: 10.1016/j.tracli.2011.03.002.

10. Monsuez JJ, Charniot JC, Vignat N, Artigou JY. Cardiac side-effects of cancer chemotherapy. Int J Cardiol. 2010;144:3-15. doi: 10.1016/j.ijcard.2010.03.003.

11. Cersosimo RJ. Monoclonal antibodies in the treatment of cancer, Part 2. Am J Health Syst Pharm. 2003;60:1631-41.

12. Rituxan - FDA prescribing information, side effects and uses. http://www.drugs.com/pro/rituxan.html. Accessed April 2016.

13. Ejaz AA, Asmar A, Alsabbagh MM, Ahsan N. Rituximab in immunologic glomerular diseases. MAbs. 2012;4:198-207. doi: 10.4161/mabs.4.2.19286

14. Garypidou V, Perifanis V, Tziomalos K, Theodoridou S. Cardiac toxicity during rituximab administration. Leuk Lymphoma. 2004;45:203-4. doi: 10.1080/10428190310001607160.

15. Millward PM, Bandarenko N, Chang PP, Stagg KF, Afenyi-Annan A, Hay SN, et al. Cardiogenic shock complicates successful treatment of refractory thrombotic thrombocytopenia purpura with rituximab. Transfusion. 2005;45:1481-6. doi: 10.1111/j.1537-2995.2005.00560.x.

16. Kanamori H, Tsutsumi Y, Mori A, Kawamura T, Obara S, Shimoyama N, et al. Delayed reduction in left ventricular function following treatment of non-Hodgkin's lymphoma with chemotherapy and rituximab, unrelated to acute infusion reaction. Cardiology. 2006;105:184-7. doi: $10.1159 / 000091416$.

17. Armitage JD, Montero C, Benner A, Armitage JO, Bociek G. Acute coronary syndromes complicating the first infusion of rituximab. Clin Lymphoma Myeloma. 2008;8:253-5. doi: 10.3816/CLM.2008.n.035.

18. Poterucha JT, Westberg M, Nerheim P, Lovell JP. Rituximabinduced polymorphic ventricular tachycardia. Tex Heart Inst J. 2010;37:218-20.

19. Lee L, Kukreti V. Rituximab-induced coronary vasospasm. Case Rep Hematol. 2012;2012:984986. doi: $10.1155 / 2012 / 984986$

20. Passalia C, Minetto P, Arboscello E, Balleari E, Bellodi A, Del Corso L, et al. Cardiovascular adverse events complicating the administration of rituximab: report of two cases. Tumori. 2013;99:288e-92e. doi: 10.1700/1390.15471.

21. Sellier-Leclerc AL, Belli E, Guerin V, Dorfmuller P, Deschenes G. Fulminant viral myocarditis after rituximab therapy in pediatric nephrotic syndrome. Pediatr Nephrol. 2013;28:1875-9. doi: 10.1007/s00467-013-2485-9.

22. Smith SA, Auseon AJ. Chemotherapy-induced takotsubo cardiomyopathy. Heart Fail Clin. 2013;9:233-42. doi: 10.1016/j.hfc.2012.12.009.

23. van Sijl AM, van der Weele W, Nurmohamed MT. Myocardial infarction after rituximab treatment for rheumatoid arthritis: Is there a link? Curr Pharm Des. 2014;20:496-9. doi: 10.2174/13816128113199990386.

24. Mulay S, Boruchov A. Recurrent and partially reversible cardiomyopathy occurring during treatment with bendamustine and rituximab. Leuk Lymphoma. 2015;56:805-7. doi: 10.3109/10428194.2014.931954.

25. Ng KH, Dearden C, Gruber P. Rituximab-induced Takotsubo syndrome: more cardiotoxic than it appears? BMJ Case Rep. 2015;2015. pii: bcr2014208203. doi: 10.1136/ bcr-2014-208203

26. Tournamille JF, Rigal-Huguet F, Pathak A, Montastruc JL, Lapeyre-Mestre M. [Cardiac effects of cytokines produced after rituximab infusion]. Bull Cancer. 2005;92:769-71.

27. Tyden G, Ekberg H, Tufveson G, Mjornstedt L. A randomized, double-blind, placebo-controlled study of single dose rituximab as induction in renal transplantation: a 3-year follow-up. Transplantation. 2012;94:e21-2. doi: 10.1097/01.tp.0000418580.88642.e1.

28. Ghielmini M, Schmitz SF, Burki K, Pichert G, Betticher DC, Stupp R, et al. The effect of Rituximab on patients with follicular and mantle-cell lymphoma. Swiss Group for Clinical Cancer Research (SAKK). Ann Oncol. 2000;11 Suppl 1:123-6. doi: 10.1023/A:1008301432453.

29. Shetty S, Ahmed AR. Preliminary analysis of mortality associated with rituximab use in autoimmune diseases. Autoimmunity. 2013;46:487-96.

30. Kyaw T, Tay C, Krishnamurthi S, Kanellakis P, Agrotis A, Tipping $\mathrm{P}$, et al. B1a B lymphocytes are atheroprotective by secreting natural IgM that increases IgM deposits and reduces necrotic cores in atherosclerotic lesions. Circ Res. 2011;109:830-40. doi: 10.1161/circresaha.111.248542.

31. Arunprasath P, Gobu P, Dubashi B, Satheesh S, Balachander J. Rituximab induced myocardial infarction: a fatal drug reaction. J Cancer Res Ther. 2011;7:346-8. doi: 10.4103/0973-1482.87003.

32. Arai Y, Tadokoro J, Mitani K. Ventricular tachycardia associated with infusion of rituximab in mantle cell lymphoma. Am J Hematol. 2005;78:317-8. doi: 10.1002/ ajh.20303.

33. Dillman RO. Infusion reactions associated with the therapeutic use of monoclonal antibodies in the treatment of malignancy. Cancer Metastasis Rev. 1999;18:465-71. doi: 10.1023/A:1006341717398.

34. Hainsworth JD, Litchy S, Barton JH, Houston GA, Hermann RC, Bradof JE, et al. Single-agent rituximab as first-line and maintenance treatment for patients with chronic lymphocytic leukemia or small lymphocytic lymphoma: a phase II trial of the Minnie Pearl Cancer Research Network. J Clin Oncol. 2003;21:1746-51. doi: 10.1200/jco.2003.09.027.

35. Coiffier B, Lepage E, Briere J, Herbrecht R, Tilly H, Bouabdallah R, et al. CHOP chemotherapy plus rituximab compared with CHOP alone in elderly patients with diffuse large-B-cell lymphoma. N Engl J Med. 2002;346:235-42. doi: 10.1056/NEJMoa011795.

36. Burkett EL, Hershberger RE. Clinical and genetic issues in familial dilated cardiomyopathy. J Am Coll Cardiol. 2005;45:969-81. doi: 10.1016/j.jacc.2004.11.066.

37. Win CM, Pathak A, Guglin M. Not takotsubo: a different form of stress-induced cardiomyopathy--a case series. Congest Heart Fail. 2011;17:38-41. doi: 10.1111/j.17517133.2010.00195.x.

Copyright $\odot 2017$ The Author(s); Published by Nickan Research Institute. This is an open-access article distributed under the terms of the Creative Commons Attribution License (http://creativecommons.org/licenses/by/4.0), which permits unrestricted use, distribution, and reproduction in any medium, provided the original work is properly cited. 